\title{
Analysis of energy consumption at the Rzeszów Wastewater Treatment Plant
}

\author{
Adam Masłoń ${ }^{1, *}$ \\ ${ }^{1}$ Rzeszów University of Technology, Department of Environmental Engineering and Chemistry, \\ al. Powstańców Warszawy 6, 35-959 Rzeszów, Poland
}

\begin{abstract}
Wastewater treatment plants can be classified as energy-intensive facilities, as they account for up to 35 percent of municipal energy consumption. Pumps and aeration systems consume a significant portion of energy within the wastewater plants in particular. The cost of energy consumption for wastewater treatment processes reaches up to $40 \%$ of the total operating cost. In case of the WWTPs with the activated sludge systems, about $50 \%$ of energy is used for aeration and mixing purposes. At WWTPs, energy consumption is often correlated with the magnitude and type of pollutant load, which can influence the treatment methods and technologies used in the WWTP. In many cases wastewater treatment plants are operated without optimized measures for process optimization. A detailed study of the energy consumption should be executed in order to determine the optimization potential. This paper presents the energy consumption in municipal wastewater treatment plant in Rzeszów (Poland). In the year 2016, parameters of raw and treated wastewater were tested. The data related to energy consumption in plants allowed us to determine the energy intensity coefficients. Total consumption was measured. Indicators of energy consumption per cubic meter and removed load were calculated.
\end{abstract}

\section{Introduction}

Wastewater treatment is an energy-intensive process. Strict standards for discharge often require energy intensive, advanced treatment technologies to be applied. As a result, the number of plants using the advanced treatment processes has been increased. Wastewater treatment plants use for up to 35 percent of the total municipal energy consumption. Electricity demand for wastewater treatment can reach up to $1 \%$ of total consumption for the whole country. Pumps and aeration systems consume a significant portion of energy within the wastewater plants in particular. The cost of energy consumption for wastewater treatment processes reaches up to $40 \%$ of the total operating cost. At the WWTPs with the activated sludge process used, about $50 \%$ of energy is used for aeration and mixing purposes [1-4]. At the wastewater treatment plants, energy consumption is often correlated to the magnitude and type of pollutant load, which can influence the treatment methods and technologies used in the WWTP. In many cases, wastewater treatment plants are operated

\footnotetext{
*Corresponding author: amaslon@prz.edu.pl
} 
without optimized measures for processes optimization. A detailed study of the energy consumption should be carried out in order to determine the optimization potential. As a result, the most potent measures can be determined for the particular plant [3-5]. The new challenge for the WWTPs is to minimize energy consumption maintaining the quality of the discharged water. Energy optimization could be obtained through reduction of the electric energy consumption of the individual units of the WWTP, but also via recovering energy from sewage sludge or wastewater [6-8].

The anaerobic digestion is a proven technology for sewage sludge treatment, which makes it possible to generate renewable energy from the same process. When anaerobic digestion technology is applied, microorganisms break down the organic matter contained in the sludge and convert it into a biogas, a mixture including mainly methane and carbon dioxide, which can be then used for electricity, heat and biofuel production. At the same time, the sludge is stabilized and its dry matter (mass) content is reduced. The benefits of anaerobic digestion process of sewage sludge are widely recognized and the technology has been well established in many countries now. Different options for use of the biogas from sewage sludge conversion exist, namely conversion to heat or power (electricity). Today, high quantities of biogas produced in anaerobic digestion in municipal wastewater treatment have enormous potential for being used worldwide [5]. Anaerobic digestion optimization is a common practice, often implemented to increase the energy self-sufficiency of WWTPs. [8]. Not only is the anaerobic digestion of sewage sludge important for maximizing of the energy production, as it also bears a great relevance within the scope of minimizing the overall treatment costs at WWTPs. Utilization of biogas for power and fuel as natural gas has many environmental benefits since it can be substituted for fossil fuels to produce electricity and vehicle fuel, reducing the carbon footprint of WWTP operations [9]. Electricity and heat autonomy indicate the ratio of energy generated to energy used in the WWTP. Larger plants achieve higher levels of autonomy due to the fact that processes there are much more efficient (higher production rate, limited losses). Complete heat autonomy is already being achieved by numerous facilities nowadays, while complete energy autonomy today is achieved only by very few, advanced and sophisticated plants [5].

This paper presents the energy consumption at the municipal wastewater treatment plant in Rzeszów (Poland, Podkarpackie Province). In the year 2016, parameters of raw and treated wastewater were tested too. The data related to energy consumption at wastewater treatment plants allowed us to determine the energy intensity coefficients. The total consumption was measured. Indicators of energy consumption per cubic meter and removed load were calculated as well.

\section{Characteristics of the Rzeszów WWTP}

The Rzeszów WWTP (Poland, Podkarpackie Province) was built between 1974-1988 and has been modernized several times since then. The average daily processing capacity estimated is $\mathrm{Q}=62500 \mathrm{~m}^{3} / \mathrm{d}$ and $400000 \mathrm{PE}$ (Population equivalents). Back in 2015, the plant has been completely modernized and expanded with a new biological wastewater treatment stream created, the effect of which was to change the capacity of the facility up to $54500 \mathrm{~m}^{3} / \mathrm{d}$ and $398000 \mathrm{PE}$.

The plant's process lines composed of a step screen, two horizontal grit separators, two radial primary clarifier units, two activated sludge reactors and four radial secondary clarifier units. Biological wastewater treatment involves integrated nutrient removal based on a conventional multistage activated sludge with a pre-emptive denitrification and denitrification in a five stages Bardenpho process. The sewage sludge line includes mechanical excessive sludge thickener, four closed aerobic digestion tanks, belt filter press 
and installation for storage and incineration of biogas obtained in the sewage sludge fermentation processes. Biogas is burned within a co-generation system and then electricity and heat are generated as a result (CHP system).

\section{Methods of energy consumption analysis}

Energy profile analysis for the wastewater treatment plant in Rzeszów was carried out on the basis of operating results recorded during the year 2016. Analysis of the removed pollutant load, gathered through wastewater treatment, in relation to energy consumption was defined. Based on the data, consumption of electricity and heat energy were identified, as well as the energy balance for the WWTP was identified. In the present paper, following energy performance indicators of wastewater treatment have been adopted:

- $\mathrm{EI}_{\mathrm{d}}$ - daily electricity consumption [MWh/d]

- $\mathrm{HEI}_{\mathrm{d}}$ - daily heat energy consumption $[\mathrm{MWh} / \mathrm{d}]$

- TEC - total energy consumption indicator [ $\mathrm{kWh}$ per $\mathrm{m}^{3}$ wastewater]

- EI - electricity consumption indicator [ $\mathrm{kWh}$ per $\mathrm{m}^{3}$ wastewater]

- HEI - heat energy consumption indicator [ $\mathrm{kWh}$ per $\mathrm{m}^{3}$ wastewater]

- $\mathrm{TER}_{\mathrm{d}}$ - daily total energy recovery $[\mathrm{MWh} / \mathrm{d}]$

- $E R_{d}$ - daily electric energy recovery $[\mathrm{MWh} / \mathrm{d}]$

- $\mathrm{HER}_{\mathrm{d}}$ - daily heat energy recovery $[\mathrm{MWh} / \mathrm{d}]$

- TEIR - total energy recovery indicator $\left[\mathrm{kWh}\right.$ per $\mathrm{m}^{3}$ wastewater]

- EIR - electric energy recovery indicator $\left[\mathrm{kWh}\right.$ per $\mathrm{m}^{3}$ wastewater]

- HEIR - heat energy recovery indicator [ $\mathrm{kWh}$ per $\mathrm{m}^{3}$ wastewater]

Indicators of energy recovery determine the generation of electricity or heat within the CHP system, taking into account the daily wastewater inflow and production of sewage sludge generated during the wastewater treatment process.

The electricity consumption (electric energy consumption) - EI - refers to the inflow $\left(\mathrm{kWh}\right.$ per $\mathrm{m}^{3}$ wastewater), often called "specific energy consumption", it is the most commonly used parameter to assess the energy effectiveness of wastewater treatment plants.

Electricity consumption values in relation to the population equivalent (PE) per year, as well with a reference to the amount of pollutants removed from wastewater, were determined. The electricity consumption related to removed $\mathrm{BOD}_{5}$ (Biological Oxygen Demand) and COD (Chemical Oxygen Demand) loads was exhibited.

\section{Evaluation of energy consumption}

\subsection{Electricity and heat energy consumption}

Throughout the year 2016, the total quantity of treated wastewater was higher than $15600000 \mathrm{~m}^{3}$, with an average of $42631 \mathrm{~m}^{3} / \mathrm{d}$. High flow ratios were recorded during the spring months (snow melt processes) and during the autumn period.

The total energy consumption amounted to $13.39 \mathrm{GWh}$, while electricity consumption was measured at the level of $7.21 \mathrm{GWh}$ and accounted for $53.8 \%$ of total consumption in 2016. The total heat energy consumption of Rzeszów WWTP was equal to $6.18 \mathrm{GWh}$, shared among the heating demand for the sludge line (anaerobic digesters, drying) and for the facility buildings and offices. The highest energy consumption was recorded in the winter months and stemmed directly from the high heat demand for heating buildings and sewage sludge before the fermentation process in anaerobic digesters. The daily electricity energy consumption was recorded at the level between 17.37 and $22.16 \mathrm{MWh} / \mathrm{d}$, with the 
average value of $19.7 \mathrm{MWh} / \mathrm{d}$ during the research period. The daily heat consumption ranged between 11.75 and $21.16 \mathrm{MWh} / \mathrm{d}$ with an average value of $16.92 \mathrm{MWh} / \mathrm{d}$. The sum of electricity and heat was on the level 32.2-40.96 MWh/d. The highest values of the $\mathrm{EI}_{\mathrm{d}}$ parameter were observed in June and for $\mathrm{HEI}_{\mathrm{d}}$ in January and December 2016. The lowest values of $\mathrm{EI}_{\mathrm{d}}$ were recorded in the period from September-December, while $\mathrm{HEI}_{\mathrm{d}}$ was the lowest from June to August. The obtained energy usage indicators recorded per 1 cubic meter of wastewater gave results such as $0.367-0.557 \mathrm{kWh} / \mathrm{m}^{3}(\mathrm{EI}), 0.314-0.509 \mathrm{kWh} / \mathrm{m}^{3}$ (HEI) and $0.762-0.981 \mathrm{kWh} / \mathrm{m}^{3}$ (TEC). The average indicators amounted to $0.468,0.397$ and $0.865 \mathrm{kWh} / \mathrm{m}^{3}$ for electricity, heat energy and total energy consumption indicator respectively. Energy consumption indicators at the wastewater treatment plant did not reflect the variation of the flow of wastewater (fig. 1). The energy intensity at the wastewater treatment plant in Rzeszów is similar to other facilities of this type. At the Krosno WWTP in Poland $\left(\mathrm{Q}=21000 \mathrm{~m}^{3} / \mathrm{d}, 117000 \mathrm{PE}\right)$ in the years 2010-2015 the electricity and heat energy consumption indicators reached the level $0.37-0.54$ and $0.3-0.6 \mathrm{kWh} / \mathrm{m}^{3}$ respectively, in turn the TEC indicator was on the level $0.67-1.11 \mathrm{kWh} / \mathrm{m}^{3}$ [10]. The HEI value was $0.62 \mathrm{kWh} / \mathrm{m}^{3}$ at the Klimzowiec WWTP (Poland) the size of which is defined by the following values: $200000 \mathrm{PE}$ and $\mathrm{Q}=29200 \mathrm{~m}^{3} / \mathrm{d}$ [11]. At the Sheboygan WWTP (USA), with average treatment capacity of $37854 \mathrm{~m}^{3} / \mathrm{d}$, the electricity consumption was shaped at the level of $0.43 \mathrm{kWh} / \mathrm{m}^{3}$ [12]. Moreover, the electric energy consumption indicator recorded is comparable with that of other countries $-0.45 \mathrm{kWh} / \mathrm{m}^{3}$ in USA, $0.52 \mathrm{kWh} / \mathrm{m}^{3}$ in Switzerland, $0.53 \mathrm{kWh} / \mathrm{m}^{3}$ in Spain, $0.56 \mathrm{kWh} / \mathrm{m}^{3}$ in Singapore, $0.64 \mathrm{kWh} / \mathrm{m}^{3}$ in United Kingdom or $0.67 \mathrm{kWh} / \mathrm{m}^{3}$ in Germany [13].

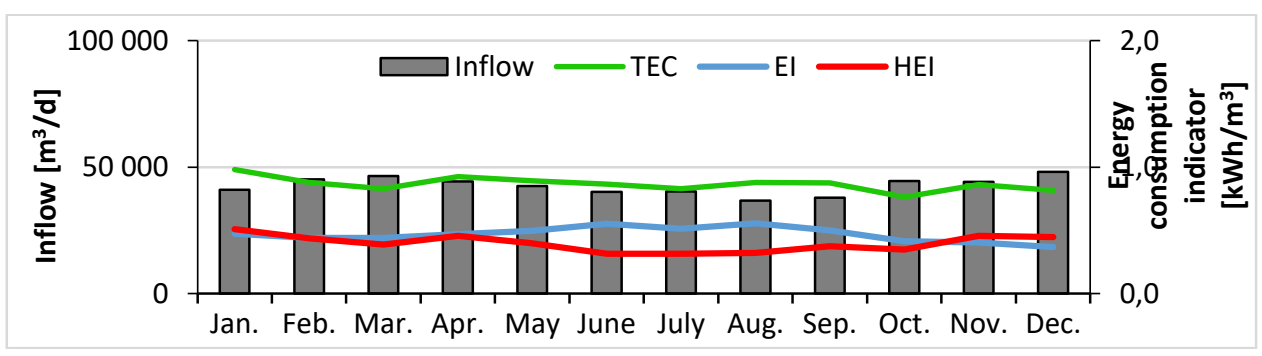

Fig. 1. Change of wastewater inflow and energy consumption indicators at Rzeszów WWTP.

The relationship between energy consumption indicators and the flow wastewater were determined (fig. 2). The electricity consumption decreases with the increasing inflow of wastewater. Very strong statistical significant relationship between EI parameter and wastewater inflow $(r=0.87)$ made the correlation between HEI and inflow moderate $(\mathrm{r}=0.49)$. For the relationship between total energy consumption and inflow the correlation coefficient value was weak $(\mathrm{r}=0.34)$.

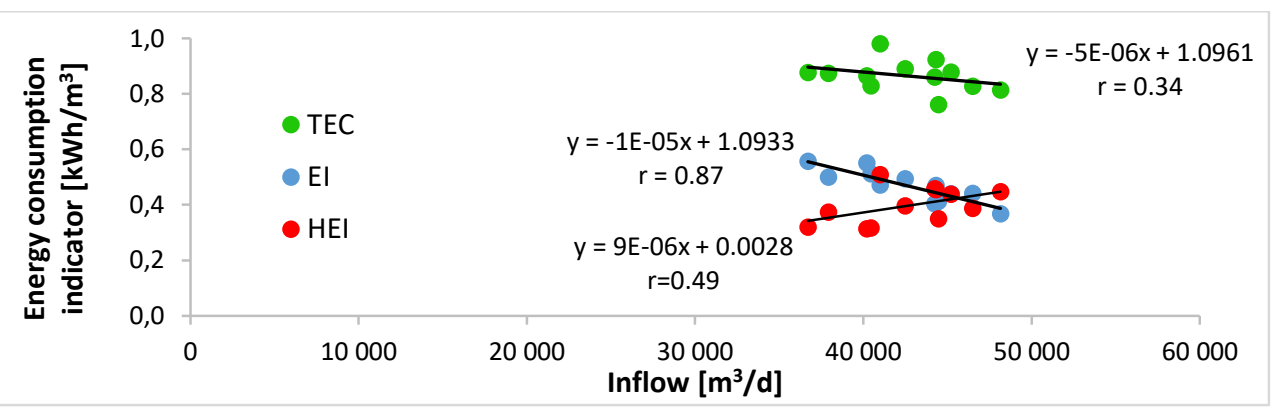

Fig. 2. Relationship between inflow and energy consumption indicators. 
Electricity consumption per population equivalent and year was $26.11 \mathrm{kWh} /(\mathrm{PE} \cdot \mathrm{y})$, $22.41 \mathrm{kWh} /(\mathrm{PE} \cdot \mathrm{y})$ and $48.2 \mathrm{kWh} /(\mathrm{PE} \cdot \mathrm{y})$ for electricity, heat energy and total energy consumption respectively. The actual population equivalent of Rzeszów WWTP was shaped at the level of $276099 \mathrm{PE}$. For the sake of comparison, electricity, heat energy and total energy consumption in Krosno WWTP was at the level of $30.53 \mathrm{kWh} /(\mathrm{PE} \cdot \mathrm{y})$, $28.58 \mathrm{kWh} /(\mathrm{PE} \cdot \mathrm{y})$ and $59.11 \mathrm{kWh} /(\mathrm{PE} \cdot \mathrm{y})[10]$.

Many others specific parameters can be used to express the energy demand efficiency of a WWTP. The electricity consumption related to removed $\mathrm{BOD}_{5}$ and COD loads exhibited itself in values ranging from 1.03 up to $1.57 \mathrm{kWh} / \mathrm{BOD}_{5}$ and from 0.49 up to $0.68 \mathrm{kWh} / \mathrm{COD}$. According to the literature, for large plants with the energy consumption parameter value higher than $100000 \mathrm{PE}$, the corresponding value was equal to $0.69 \mathrm{kWh} / \mathrm{COD}$ [3]. Electricity consumption increases also with the increasing influent pollution concentration $\left(\mathrm{COD}, \mathrm{BOD}_{5}\right)[1]$.

\subsection{Wastewater energy recovery and energy production}

Energy production, with the use of process involving burning of biogas generated from the sewage sludge, has been commonly used at WWTPs now [1, 8]. Daily biogas production reached the level from $5473 \mathrm{~m}^{3}$ in October to $8041 \mathrm{~m}^{3} / \mathrm{d}$ in June, with the average value of $6637.9 \mathrm{~m}^{3} / \mathrm{d}$ (fig. 3). During the year 2016 the total biogas generation at the plant was equal to $2427489 \mathrm{~m}^{3}$. The biogas production rate (BPR) was contained in the range from 0.123 to $0.2 \mathrm{~m}^{3}$ per $\mathrm{m}^{3}$ wastewater.

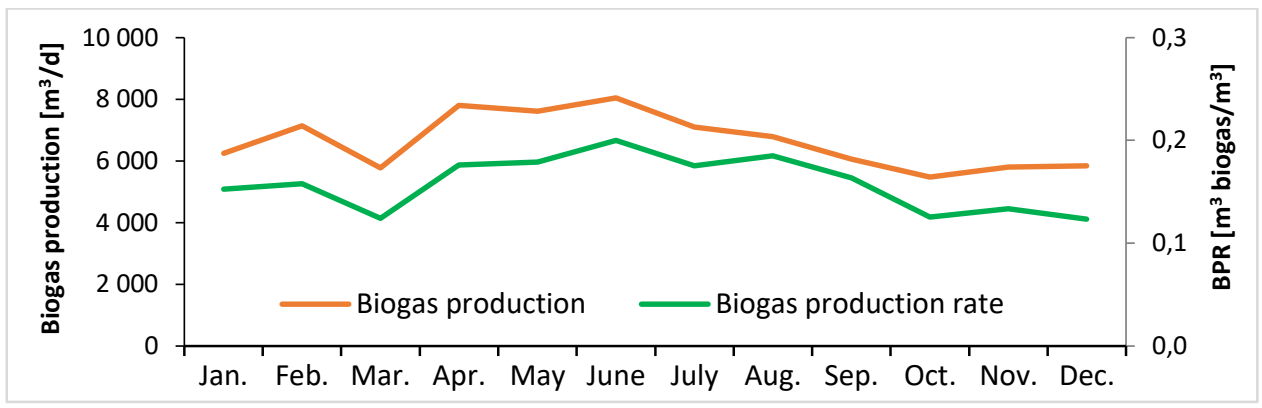

Fig. 3. Volume of biogas production, achieved from the sewage sludge at Rzeszów WWTP.

The installed CHP system produces ca. $1035 \mathrm{~kW}$ of electricity and ca. $1530 \mathrm{~kW}$ of heat. Furthermore, another two boilers produce $1440 \mathrm{~kW}$ of heat. Daily electric energy $\left(E R_{d}\right)$ and daily heat energy recovery $\left(\mathrm{HER}_{\mathrm{d}}\right)$ were within the range of $11.78-17.44 \mathrm{MWh} / \mathrm{d}$ and 11.75-20.34 MWh/d respectively. The results show that daily total energy recovery varies from 26.0 to $37.27 \mathrm{MWh} / \mathrm{d}$ with the average value of $30.65 \mathrm{MWh} / \mathrm{d}$.

The total energy generation from biogas was contained between 3.72 and $5.67 \mathrm{kWh} / \mathrm{m}^{3}$ with the average value of $4.67 \mathrm{kWh} / \mathrm{m}^{3}$. In relation to the above, the electricity and heat energy production was as high as $2.02-2.48 \mathrm{kWh} / \mathrm{m}^{3}$ and $1.57-3.25 \mathrm{kWh} / \mathrm{m}^{3}$ respectively (fig. 4). At other plants electricity generation from biogas reached the level of 1.9-4.8 kWh/m $/ \mathrm{m}^{3}$ (Mielec WWTP, Poland) [14], 3.82-4.51 kWh/m $\mathrm{m}^{3}$ (Krosno WWTP) [10]. However at these plants, in anaerobic digesters, the process of co-fermentation of sewage sludge with waste fats takes place quickly, which enhances the production of biogas and methane. Literature also indicates the low electric energy production rates, when biogas is used, e.g. $0.2 \mathrm{kWh} / \mathrm{m}^{3}$ (Poprad WWTP, Slovakia), $1.21 \mathrm{kWh} / \mathrm{m}^{3}$ (Trnava WWTP, Slovakia), $2.0 \mathrm{kWh} / \mathrm{m}^{3}$ (Bratislava Central WWTP, Slovakia) [1]. 


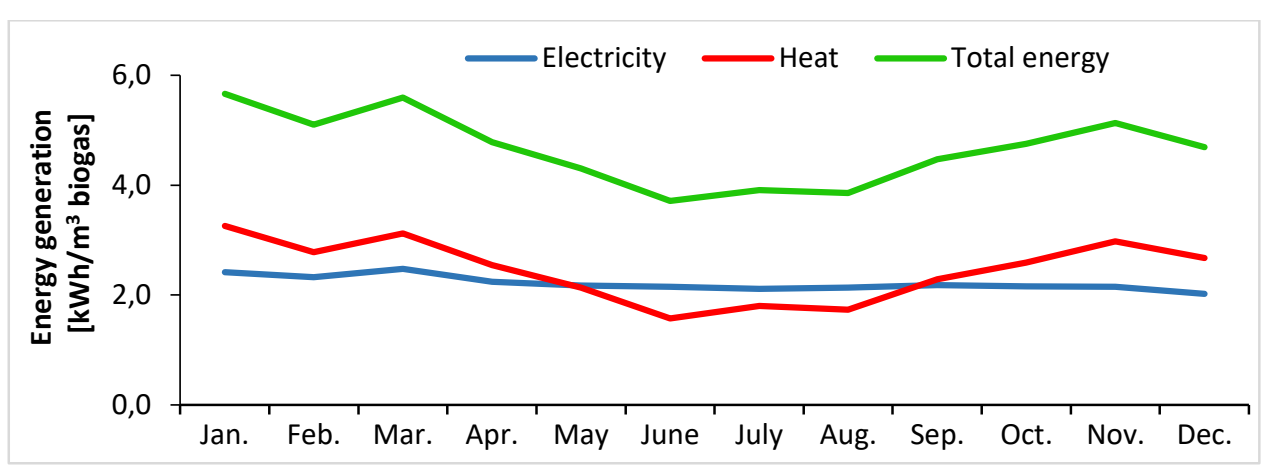

Fig. 4. Electricity, heat and total energy generation from biogas at wastewater treatment plant.

Analysis of energy recovery indicators allowed us to determine the energy generation efficiency of wastewater treatment process. During the research period, the total energy recovery indicator was placed at the level of $0.52-0.77 \mathrm{kWh} / \mathrm{m}^{3}$ with the average value of $0.52 \mathrm{kWh} / \mathrm{m}^{3}$. The highest values of TEIR were observed in January and April 2016. Values of EIR and HEIR indicators have allowed us to obtain results such as $0.25-0.43 \mathrm{kWh} / \mathrm{m}^{3}$ and $0.26-0.41 \mathrm{kWh} / \mathrm{m}^{3}$. The average of electric energy and heat energy recovery indicators was 0.3 and $0.31 \mathrm{kWh} / \mathrm{m}^{3}$ respectively (fig. 5).

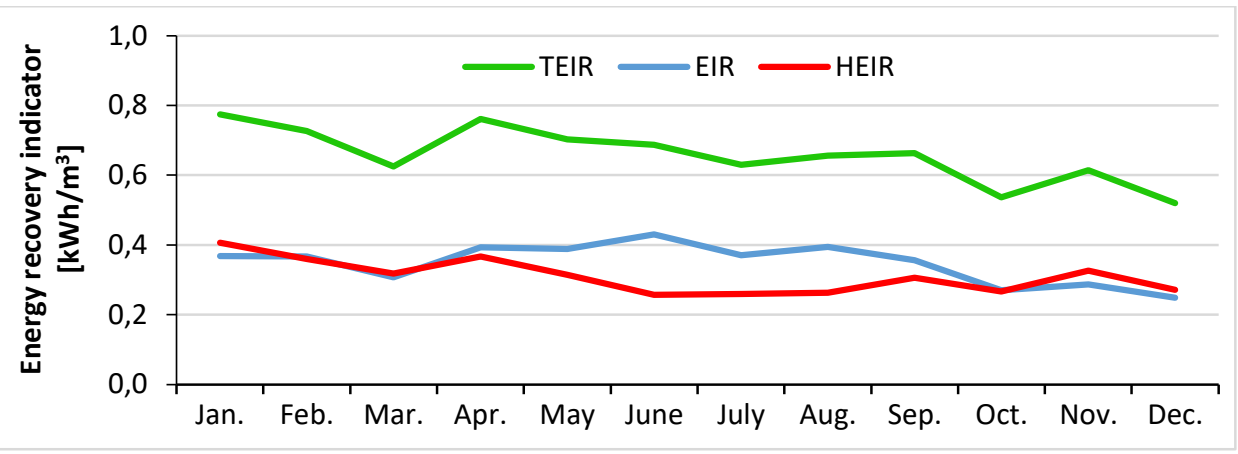

Fig. 5. Energy recovery indicators recorded at wastewater treatment plants in Rzeszów.

At other plants energy recovery in relation to treated wastewater is diversified. In case of the Krosno WWTP, during the years 2010-2015, energy recovery indicators were at the level of $0.25-0.40 \mathrm{kWh} / \mathrm{m}^{3}$ (EIR), $0.3-0.6 \mathrm{kWh} / \mathrm{m}^{3}$ (HEIR) and $0.55-0.89 \mathrm{kWh} / \mathrm{m}^{3}$ (TEIR) [10]. For the sake of comparison, the total energy recovery at the Steinhof WWTP (Germany) with treatment capacity of $61643 \mathrm{~m}^{3} / \mathrm{d}$ amounted to $0.858 \mathrm{kWh} / \mathrm{m}^{3}$ via Combined-Heat-Power [12].

\subsection{Energy balance at wastewater treatment plant}

The anaerobic digestion technology plays an important role in energy self-sufficiency of a WWTP [8]. The biogas energy makes it possible to meet $74.3 \%$ of the electrical and $95.5 \%$ of the needs, in relation to the overall energy consumption of the wastewater treatment plant. The rate between total energy generation and consumption in case of the Rzeszów WWTP was shaped at the level between 71.1-91.6\% with the average value of $83.6 \%$. Maximum electrical energy self-sufficiency was noted in February $(83.2 \%)$ and April (83.9\%) and minimum was recorded in October $(65.5 \%)$. Heat production at plant resulted from demand for heating of the anaerobic digesters and of buildings and offices 
during the winter period. Minimum self-sufficiency referring to heat energy was seen in December (73.8\%), whereas maximum values 100\% were recorded in February-March and June-September (fig. 6-8).

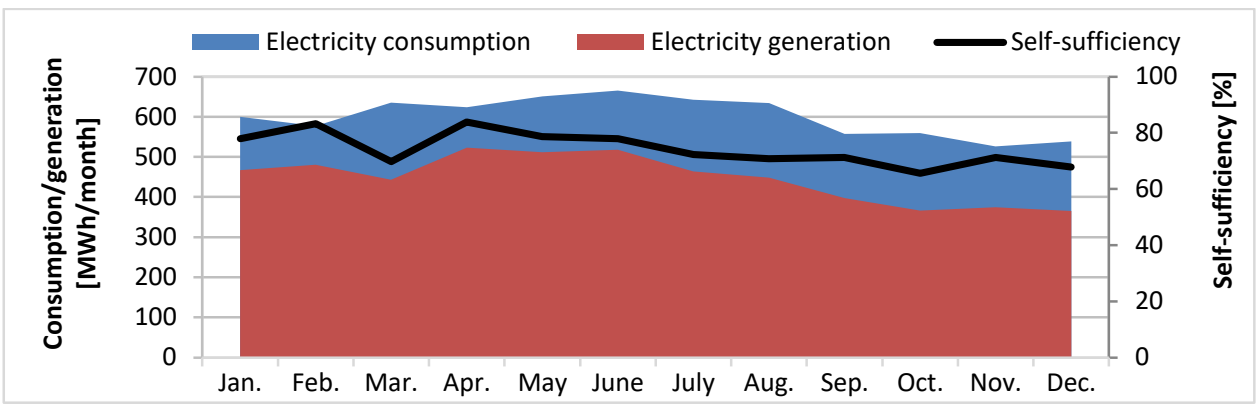

Fig. 6. Electricity balance at the Rzeszów WWTP, during the year 2016.

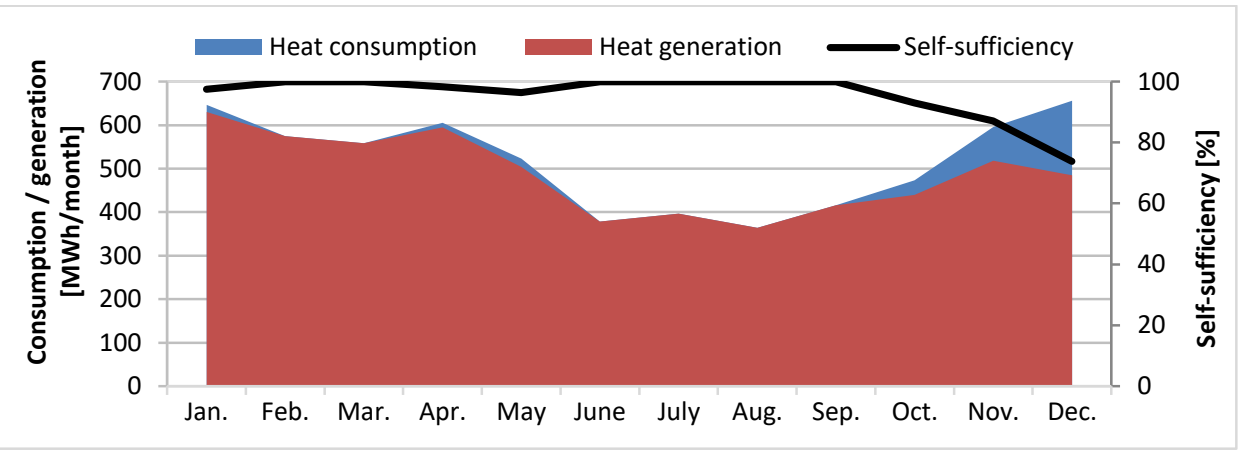

Fig. 7. Heat energy balance at the Rzeszów WWTP, during the year 2016.

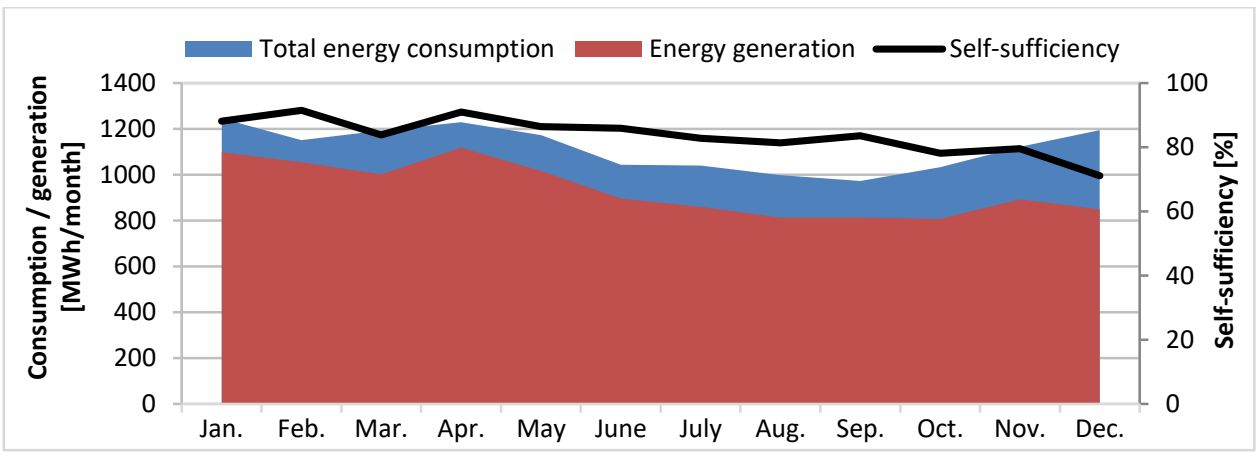

Fig. 8. Total energy balance at the Rzeszów WWTP, during the year 2016.

After comparing the obtained results with the literature data, it can be concluded that Rzeszów WWTP has a very high energy potential. For the sake of comparison, we may state the average degree of cover the electricity consumption at the Krosno WWTP was achieved at the level of 70\% [10]. At the WWTPs in Slovakia, energy self-sufficiency was equal to 66\% (Bratislava Central WWTP), 64\% (Trnava WWTP) and 52\% (Martin WWTP) [1]. 


\section{Conclusions}

Wastewater treatment is an energy-intensive process and energy consumption is often the main operational cost component for the WWTPs. Electricity and heat energy is consumed in wastewater treatment systems every year, and there is a large potential of saving the said energy within that process. Furthermore, unit energy cost of wastewater treatment may be significantly affected by wastewater treatment capacity and technology. In this paper, energy consumption of wastewater treatment plant in Rzeszów was explored. The results show that the total energy consumption of Rzeszow WWTP in 2016 year was placed at the level of about $0.865 \mathrm{kWh} / \mathrm{m}^{3}$ and $48.2 \mathrm{kWh} /(\mathrm{PE} \cdot \mathrm{y})$. The average indicators for electricity and heat energy consumption amounted to 0.468 and $0.397 \mathrm{kWh} / \mathrm{m}^{3}$ respectively. The electric energy consumption was much lower, than the corresponding values present at other plants and in other countries. This result may be tied to the very advanced treatment technologies used and to the low water quality requirements of wastewater treatment in Rzeszów. Anaerobic digestion technology with CHP system used at the Rzeszów WWTP plays an important role in energy self-sufficiency. The biogas energy makes it possible to meet $74.3 \%$ of the electrical and $95.5 \%$ of the heat needs, in relation to the overall energy consumption of the wastewater treatment plant. The relation between total energy generation and consumption at Rzeszów WWTP had an average value of $83.6 \%$. During the research period total energy recovery indicator was placed at the level $0.52 \mathrm{kWh} / \mathrm{m}^{3}$. The average of electric energy and heat energy recovery indicators were recorded at the level of 0.3 and $0.31 \mathrm{kWh} / \mathrm{m}^{3}$. Identification of the WWTP energy balance was the first, but very important step in the process of developing better biogas utilisation scheme. The data describes the real situation seen at the Rzeszow WWTP, but the similar results can be expected at other WWTPs in Poland.

\section{References}

1. I. Bodík, M. Kubaská, Environ. Prot. Eng. 39, 2 (2013)

2. D. Panepinto, S. Fiore, M. Zappone, G. Genon, L. Meucci, Appl. Energ. 161 (2016)

3. S. Longo, B.M. d'Antoni, A. Chaparro, A. Cronrath, F. Fatone, J.M. Lema, M. Mauricio-Iglesias, A. Soares, A. Hospido, App. Energ. 179 (2016)

4. J. Henriques, J. Catarino, J. Clean. Prod. 142 (2017)

5. N. Bachmann, Sustainable biogas production in municipal wastewater treatment plants (IEA Bioenergy, 2015)

6. K.J. Chae, J. Kang, Energ. Convers. Manage. 75 (2013)

7. J. Frijns, J. Hofman, M. Nederlof, Energ. Convers. Manage. 65 (2013)

8. G. Silvestre, B. Fernández, A. Bonmatí, Energ. Convers. Manage. 101 (2015)

9. Y. Shen, J.L. Linville, M. Urgun-Demirtas, M.M. Mintz, S.W. Snyder, Renew. Sust. Energ. Rev. 50 (2015)

10. K. Trojanowicz, Ł. Karamus, Forum Eksploat. 4, 85 (2016)

11. P. Banaszek, Kierunek Wod-Kan. 3 (2014)

12. H. Wang, Y. Yang, A.A. Keller, X. Li, S. Feng, Y. Dong, F. Li, Appl. Energ. 184 (2016)

13. F. Hernández-Sancho, M. Molinos-Senante, R. Sala-Garrido, Sci. Total Environ. 409 (2011)

14. A. Masłoń, S. Pazdro, W. Mroczek, Forum Eksploat. 4, 79 (2015) 